\title{
The growth of mass tourism in the Mediterranean, 1950-2010:
}

\author{
Carles Manera, Antònia Morey \\ Department of Applied Economics University of Balearic Islands
}

\begin{abstract}
The explosion of mass tourism since the end of the Second World War has had a tangible effect on crucial flows of manpower, investment and production strategy towards the leisure economy in a large part of the world, with changes that take us back to what occurred two hundred years earlier in the heat of the Industrial Revolution. However, perhaps it is in particular areas (as was the case with the thrust of industrialisation) such as the Mediterranean basin, where this view can be identified more accurately. Both approaches are reflected in the key objectives of the work.
\end{abstract}

Keywords: Techno-economics changes, Mediterranean Area, Tourism Economics.

\section{Introduction}

Within the context of economic history, it is now commonplace to talk about the Industrial Revolution as a fundamental phenomenon which transformed the evolution of mankind from the $18^{\text {th }}$ century onwards. The process, understood here as a long path which responds wholly to drastic, ground-breaking factors (according to the latest research undertaken by economic historians), has however emphasised the importance of extreme changes in the fields of technology, demography, economics, sociology and culture. In spite of the different interpretations of the issue, a common link between them all would undoubtedly be the turnabout resulting, albeit gradually, from the emergence of this "Great Transformation", in the sense used by K. Polanyi, in the composition of the employment market and of the economic structure of nations since 1770. In short, the growth in assets, both personal and generated by income, allocated to the secondary sector. This is the idea presiding over this research, in two specific directions. On the one hand, the explosion of mass tourism since the end of the Second World War has had a tangible effect on crucial flows of manpower, investment and production strategy towards the leisure economy in a large part of the world, with changes that take us back to what occurred two hundred years earlier in the heat of the Industrial Revolution. However, and here is the second element to be considered, perhaps it is in particular areas (as was the case with the thrust of industrialisation) such as the Mediterranean basin, where this view can be identified more accurately. Both approaches are reflected in the key objectives of the work.

The research is based on statistics provided by the World Tourism Organization (WTO), existing with certain gaps since the 1940s until the present day; and materials from Spain's National Statistics Institute (INE), Spain's Government Department of Tourism and the resources of the Official Chamber of Commerce, Industry and Shipping of Palma de Mallorca (COCIN). All of this documentation, supported by the corresponding bibliography, has made it possible to reconstruct and systemise the data required in order to meet the two fundamental objectives mentioned above. To this end, the research is arranged into the following sections. The first section will discuss the major figures available on the growth of tourism since the Second World War, whilst at the same time outlining the fundamental theoretical keystones of the study: the claim with regard to a particular techno-economic paradigm in the case of mass tourism, involved in the fifth technological revolution seen since the Industrial Revolution. The second section will deal specifically with the Mediterranean in its main tourism elements, based on the sources available: number of visitors, overnight stays and tourism expenditure. Finally, some conclusions are offered in order to summarise the work.

\section{From economic history ... to the future? Mass tourism as a new techno-economic paradigm}

Tourism is one of the most important and dynamic economic activities of our times, with significant growth since the immediate post-war period, as shown in table 1 and the accompanying graphs. They confirm the following. Firstly, the striking increase in the number of tourists between 1950 and 2000: from 25 million to 687 million, with a clear European predominance. This -and here is the second element-, combined with the development in America, always consists of a percentage higher than 75 per cent in the worldwide attraction of tourists, an outstanding piece of data. Thirdly, the neglected destinations, Asia-Pacific, Africa and the Middle East, show delayed progress, but with a clear strength in the first of these: from 0.79 per cent in 1950 it increased to 16.77 per cent in 2000 , and it can therefore be stated that, in the long term, this is the area which, relatively speaking, is attracting a greater share of tourism in the international markets. This fact infers a change in the tourism geography of the world, especially in the forthcoming years. In 2002, the ten main tourist destinations received half of the international arrivals of visitors, who accounted for more than 50 per cent of 
the world's tourism expenditure. Of these ten, nine are in European countries and the United States. However, a look at economic history shows a loss of strength on the part of Europe and America as destinations. In 1950, 97 per cent of the world's tourism gravitated towards those continents. In 2000, the proportion fell to 78 per cent and, according to WTO predictions, by 2020 this figure will be reduced to 64 per cent. At the other extreme are the areas of Asia and the Pacific which, as mentioned, have been playing a spectacularly more dominant role, to the tune of 27 per cent in 2020. Similar conclusions have been reached for the Middle East and Africa, which have redoubled -with further increases predicted- their roles as world tourist destinations. We can therefore see a reduction in the market share in Europe and America and a certain "peripherization" of the expansion of tourism

This spectacular growth, seen from the demand side, can only be explained by the increase in income and the establishment of week-long holidays in the more developed countries. The Keynesian-type economic policies, promoted since the 1940s -in all of their variations and peculiarities- entailed a set of actions designed to stimulate added demand. In this respect, the majority of studies on tourism demand demonstrate that it is determined by income and prices. With regard to income elasticity, it is greater than one; in other words, tourism is a luxury good. Price elasticity, on the other hand, shows a more irregular behaviour: the price is a less relevant variable in the consumption of long trips, whereas for short-distance destinations this elasticity is greater. However, the historical perspective confirms that the growth in the volume of international tourists is greater than the development of the global economy: over the last fifty years, for every increase of one percentage point in the per capita income of the world's inhabitants, the increase in the number of travellers has risen by more than three points

Table 1. Inte mational arrivals of touris ts (1950-2002) and forecasts (2003-2020)

\begin{tabular}{|l|c|c|c|c|c|c|c|c|}
\hline Large Regions & 1950 & 1960 & 1970 & 1980 & 1990 & 2000 & 2010 & 2020 \\
\hline A frica & 0,5 & 0,8 & 2,4 & 7,4 & 15 & 27,4 & 47 & 77,3 \\
\hline A merica & 7,5 & 16,7 & 42,3 & 61,4 & 93 & 128 & 190,4 & 282,3 \\
\hline A sia-Pacific & 0,2 & 0,9 & 6,2 & 24,3 & 57,7 & 115,3 & 205,8 & 416 \\
\hline Europe & 16,8 & 50,4 & 113 & 186 & 280,6 & 392,7 & 527,3 & 717 \\
\hline Middle East & 0,2 & 0,6 & 1,9 & 7,5 & 9,7 & 24 & 35,9 & 68,5 \\
\hline World Total & 25,2 & 69,4 & 165,8 & 286,6 & 456 & 687,4 & $1.006,40$ & $1.561,10$ \\
\hline Percentages of the total & & & & & & & & \\
\hline Large Regions & 1950 & 1960 & 1970 & 1980 & 1990 & 2000 & 2010 & 2020 \\
\hline A frica & 1,98 & 1,15 & 1,45 & 2,58 & 3,29 & 3,99 & 4,67 & 4,95 \\
\hline A merica & 29,76 & 24,06 & 25,51 & 21,42 & 20,39 & 18,62 & 18,92 & 18,08 \\
\hline A sia-Pacific & 0,79 & 1,3 & 3,74 & 8,48 & 12,65 & 16,77 & 20,45 & 26,65 \\
\hline Europe & 66,67 & 72,62 & 68,15 & 64,9 & 61,54 & 57,13 & 52,39 & 45,93 \\
\hline Middle East & 0,79 & 0,86 & 1,15 & 2,62 & 2,13 & 3,49 & 3,57 & 4,39 \\
\hline World Total & 100,00 & 100,00 & 100,00 & 100,00 & 100,00 & 100,00 & 100,00 & 100,00 \\
\hline
\end{tabular}

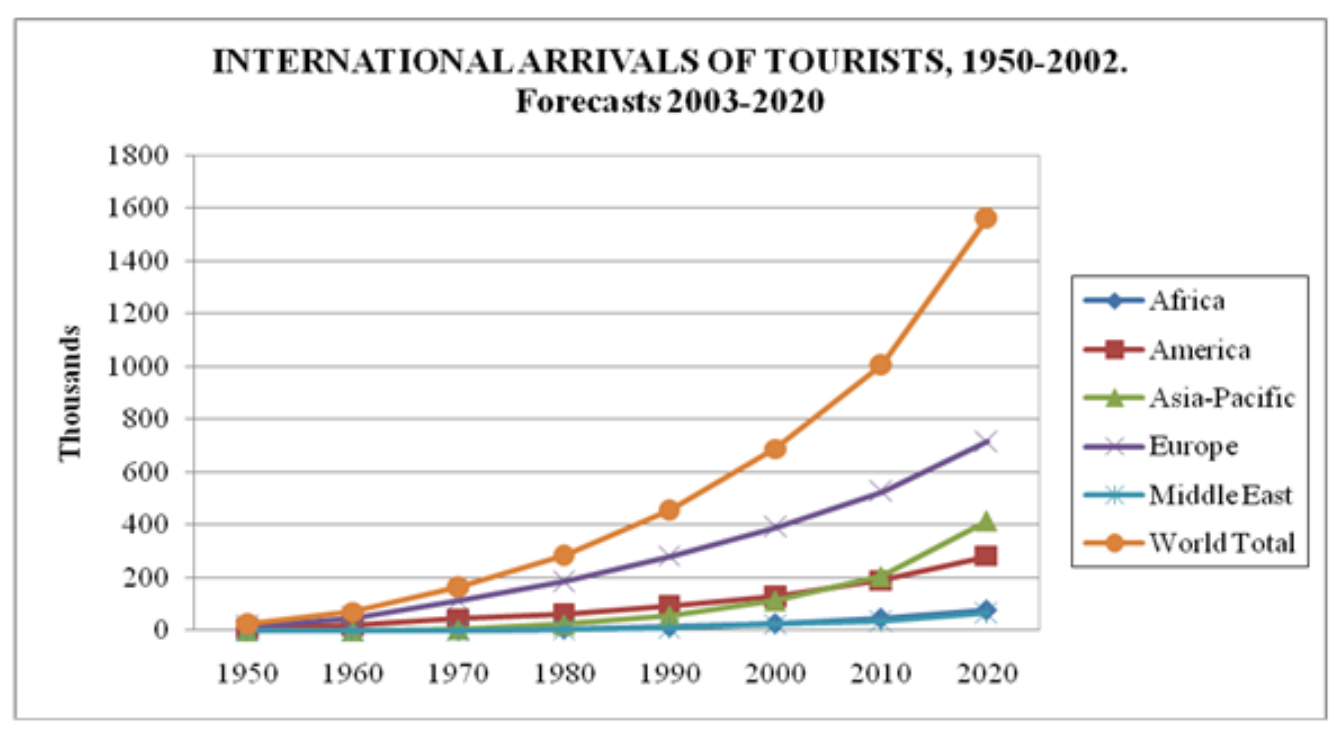




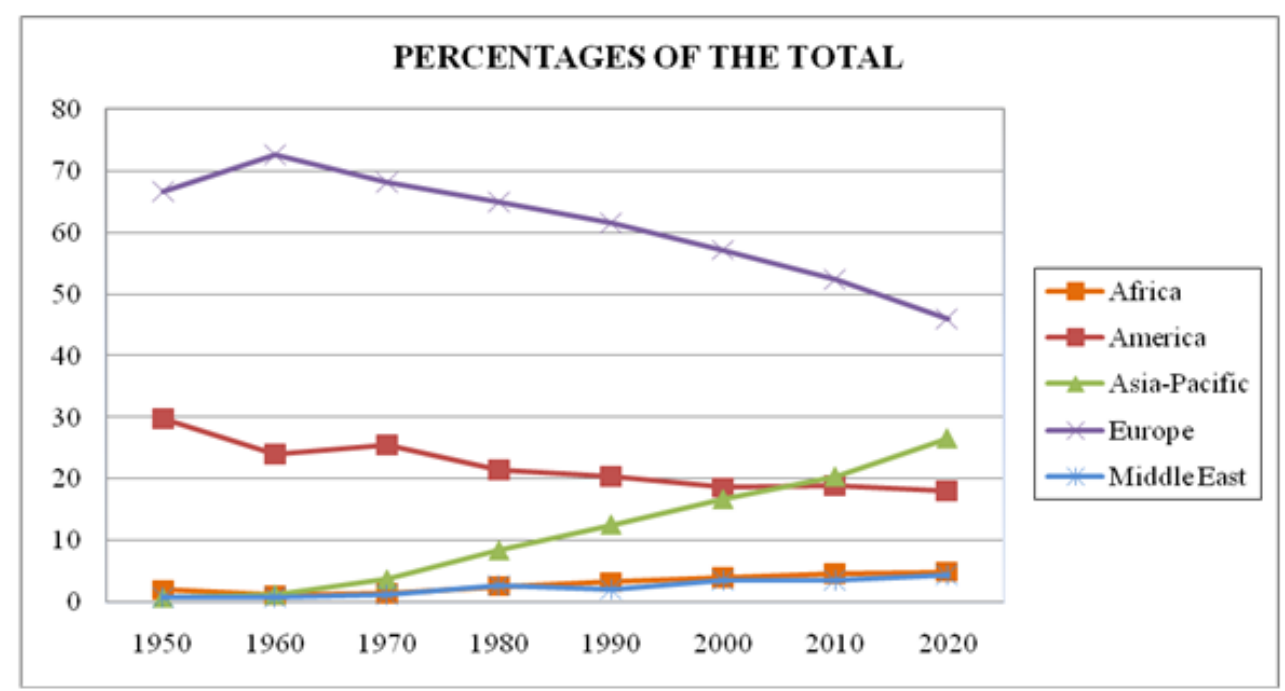

SOURCE: Own work based on WTO statistics.

The prediction of the world volume of tourists made by the WTO, estimating growth rates of almost 4 per cent -which would mean going from 702 million in 2002 to 1.561 billion by 2020- is supported, on the one hand, by the increase in the disposable income of citizens and, on the other, by certain socio-demographic changes occurring in the more advanced countries (a rise in the number of childless couples and single-family homes, better levels of education, the proportion of older people and the growth in the number of retired people). The figures shown in table 1 represent the growth in an economic activity whose scarce prior experiences - what we could classify as the prehistory of mass tourism, up until the 1930s- are in clear contrast to the richer and more extensive data available from the 1940s onwards. The growth in tourism, measured by such an illustrative indicator as the number of visitors to a specific area, has experienced the most evident growth in global economic activity as a whole with the start of the post-war period. And as in the case of industrialisation, a visible "attractor" can also be seen here - to use the expression of C. Pérez-, a geography full of natural resources to be enjoyed and not just "apprehended", which exemplifies a whole potential for development and, in parallel, is capable of speeding up innovation and change among the pioneers who contribute to revealing and supporting the process. This becomes imitative at the point of the initial successes: unconscious talent flows, emulation grows, and the chaotic, disorganised beginnings give way to the submission to certain practical rules for operating the new activity. The turnabout is clear: national or regional economies demonstrate obvious signs in the structures of their employment markets and in the gradual contribution of the emerging activity to generating income.

Perhaps we are facing a "technological revolution" -in the sense of the techno-economic paradigm expressed by C. Pérez- which involves a set of technologies, of products, of new - and very dynamic industries, which are encouraging a different development in the long term. Along this line of interpretation, the fifth technological revolution (the age of IT and telecommunications) stimulates a series of factors which clearly apply to the world of mass tourism already established: the intensive use of information -with solid foundations in microelectronics-, online organisation, the importance of knowledge applied to the new activity, the proliferation of market niches which respond to changes in demand, global and instantaneous communication -via the Internet- and adaptability and national and international cooperation, in the form of clusters. The host of innovations resulting from this complex change leads in turn to other infrastructures, other products and processes. The approach to rejuvenating industries which are now mature, the different approaches to production organisation, a greater applied ability -involving increases in productivity in the first stages of the phenomenon- and, in short, the structural changes which, as a whole, constitute this economic shift, leads to an essential corollary: the adoption of new growth engines, in certain expansive areas of economic development

\section{The Mediterranean as a tourist "attraction"}

What has changed in the Mediterranean economy since 1945? And what relevant role did, and does, mass tourism perform in that transformation? These two questions are fundamental. There is an awareness of the complexity of the answer, as it is difficult to establish certain generic parameters for a very disparate geographic and economic reality, with different growths. First of all, we are talking about twenty-two genuine situations, with very important historical frameworks and with substantial political changes experienced over recent years. But an initial confirmation seems clear: on this interwoven "planet" -in the words of F. Braudelone of the great advancements has been the establishment of a service economy. 
The countries of the basin comprise a total of twenty-two States which share the common characteristic of bordering the Mare Nostrum. All of them together constitute one of the world's main destinations: with more than 702 million visitors in 2002, representing a third of the world's international tourist arrivals, and a revenue of 134 billion dollars, 28 per cent of the world's tourism expenditure. The Mediterranean bases a large part of its economic activity on this provision of services. In the same year, the impact of tourism expenditure amounted to around 3.7 per cent of the gross national product. The variety found on the Mediterranean is scarcely debateable. From the traditional sun and sand locations, such as Spain, Turkey and Tunisia, to those renowned for their culture and heritage, particularly in the cases of France and Italy, the coasts of this enclosed sea form part of an area visited, mostly, for the purpose of leisure and holidays, although, as with the world's tourism flows, other motives, such as health, professional requirements or business commitments, gradually persist and are facets which diversify destinations and the types of clients. The Europeans are the most frequent visitors -nine out of ten tourists-, whilst far behind are the Americans -less than 5 per cent of travellers- and, more recently, we have witnessed the increase in tourists from the Middle East and from South-East Asia -groups which have doubled their market share between 1990 and 2002 (from 7 to 13 million arrivals).

The historical and economic area of the Mediterranean is a huge attraction for the leisure economy. The figures on the arrivals of tourists to its cities, as shown in the graph, support this assertion.

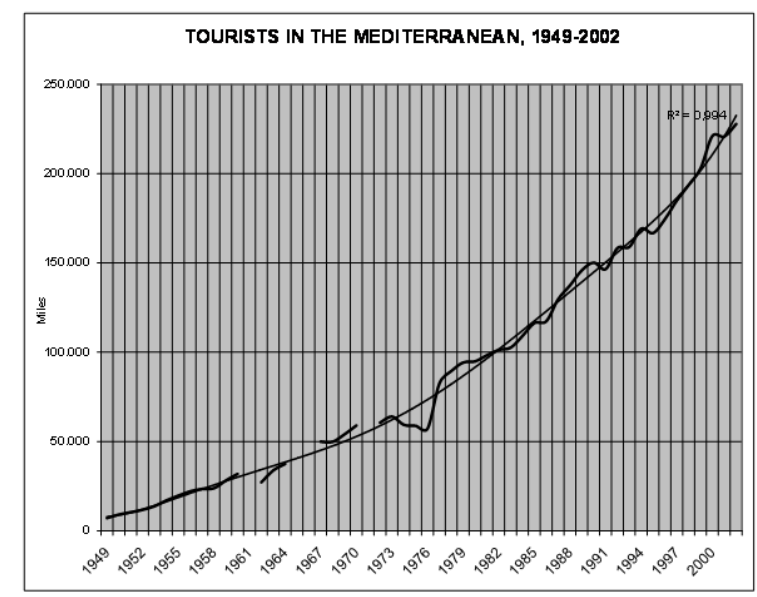

SOURCE: Own work based on WTO statistics. The data processed corresponds to: Albania, Algeria, Cyprus, Egypt, Spain, France, Greece, Israel, Italy, Libya, Lebanon, Malta, Morocco, Monaco, Palestine (which is not included in the collection of data as there was no complete series), Syria, Tunisia, Turkey and the following countries of the former Yugoslavia: Bosnia-Herzegovina, Croatia, Slovenia and Serbia and Montenegro (up until 1991 Yugoslavia is taken as a whole). As an exception, Macedonia was also included, although it is not a country with a Mediterranean coast, in order to standardise the data relating to the former Yugoslavia.

As can be seen, the growth since the 1950s is impressive. The curve shown has few deviations: from 7 million tourists in 1949 to 227 million in 2002, few economic activities have multiplied one of their reference indicators by thirty-three (even during the course of the so-called "glorious" thirty-year period between 1945 and 1973).

\section{Towards some conclusions}

The observation of this half century of tourism movement enables us to make some specific comments, of a general nature:

1. Five clear phases of development can be seen: an expansive phase, between 1949 and 1972, which is common to the parallel progress made by economic activity as a whole; the next phase, of clear contraction, between 1973 and 1978, due to the economic crisis and political instability in a large group of countries (Israel, Libya, Lebanon, Syria, Tunisia, Turkey); a third phase beginning with the new thrust from 1979 to 1990 , in contrast to the world's economic situation, still shaken by the impact of the war between Iran and Iraq and by the consequences of the second oil crisis; a fourth, more relevant, period, in response to the light and ephemeral contraction of 1991-1993, in which political unrest moved to the more eastern parts of the Mediterranean; and, finally, a new period of relaunch beginning in 1994 and lasting until the beginnings of the new century. 
2. The data gathered does not identify all of the sections of the life cycle of tourism, as proposed by R.W. Butler. This author suggests six stages in the tourism economy which are characterised by their display of different rates of growth in demand. In the first, known as the "exploration" stage, the number of tourists is low, thus resulting in hardly any changes. In the second, the "involvement" stage, the amount of visitors begins to grow at increasingly high rates to the point where it reaches its maximum in the full "development" phase, i.e., the third stage. From that point on, the number of tourists expands, albeit with less intensity, to end, shortly after, with zero growth in the period that Butler calls the "stagnation" stage. Lastly, two possibilities are clear: "rejuvenation" or "depression". WTO tourism predictions, shown in table 1, and which need to be viewed extremely cautiously, do not lead us to think that, in the Mediterranean as a whole, the maturity stage has now been established. On the contrary, in fact, the movement of tourists seems less affected by the transformations and ups and downs of the international economy than other productive sectors. However, this is very slippery ground which cannot be commented on thoroughly enough, taking into account that these forecasts and predictions may need to be reviewed.

3. Nevertheless, the status of tourism in each of the countries is different. In fact, the destinations could be classified into three main groups. Firstly, and continuing with the terminology of industrial history, the first comers, the pioneers, i.e., Spain, France and Italy; these three nations dominate Mediterranean tourism, as their market share ranges from 75 per cent to 95 per cent. This leadership is, in turn, shared worldwide with the United States and China. These destinations have a long life cycle, as they have been displaying a particular development model for several decades. Secondly, the late comers, those who are new to the process, Greece, Egypt, Turkey, Tunisia, Morocco, nations which are making progress in the achievement of their tourism objectives, but which do not manage to grasp significant market shares from the leaders due to the powerful expansion of the sector as a whole, as shown by the figures provided. These five are different from others, which have also experienced a significant increase in the number of tourists over recent years, because they display a regular and constant growth path, maintained for almost fifteen years. This leads us to consider them as nations which are emerging, yet established in the tourism economy, as their paths do not respond to particular climates. A third group consists of the remaining countries, more modest in size, which have been waking up to the tourism phenomenon relatively recently. These are destinations with erratic behaviour. They are countries (Albania, Algeria, Israel, Libya, Malta, and Monaco, among others) whose tourism variables have increased at a rate considerably below the Mediterranean average, or whose figures for arrivals, overnight stays and tourism expenditure have decreased (such as Israel). There are three fundamental reasons for the unpredictable behaviour of these destinations. Firstly, political instability, combined with the emergence of violent phenomena of a political/religious nature. This is illustrated by the cases of Algeria (where there were over one hundred thousand fatalities between 1992 and 1998 due to attacks by Islamic fundamentalists) and Israel (with the start of a new intifada in September 2000). Secondly, in spite of the growth in tourism in certain countries (Albania), these do not maintain it with the same intensity or for a long period of time. Finally, there are States (Malta, Monaco) which display similar characteristics to the traditional Mediterranean nations: it has been several decades since they were significant and they have begun to show signs of decline, with growth rates of the tourism variables at lower levels than their Mediterranean rivals.

There is no clear process of the replacement of first comers by late comers, as was so evident in the Industrial Revolution. There is no changeover; moreover, the pioneers continue to progress, although, in specific examples of regional economies, reasonable signs of saturation can be seen.

From this point onwards, the work must first of all be steered in the following directions:

1. To analyse in depth the bibliographic records in relation to tourism economics and economic change.

2. To demonstrate with accurate indicators the claims that have been made: greater growth in tourism in relation to general economic growth, advancement of "tertiarisation", among others.

3. To make use of the statistical material available, with a focus on certain key areas:

- The diversification of European economic structures since 1945.

- Tourism expenditure.

- The interrelation of markets between the first comers and the late comers.

4. The regional breakdown of national figures, as the tourism phenomenon calls for more localised analysis in the spatial environment (Fujita-Krugman-Venable: new economic geography). Here, a thorough analysis of the EUROSTAT databases will be a determining factor, although the chronological limits of these materials are severe.

5. The inclusion of the innovation processes that are inherent to mass tourism within the framework of the fifth technological revolution (Pérez). 


\section{Bibliography}

[1]. AGARWAL, S. (1994), "The resort cycle revisited: implication for resorts", en C. COOPER-A. LOCKWOOD (Edits.), Progress in Tourism, vol. 5 (Wiley).

[2]. AGARWAL, S. (1997), "The resort cycle and seaside toruisme: an assessment of its applicability and validity", Tourism Management, 18 (2)

[3]. AGARWAL, S. (2002), "Restructuring seaside tourism. The resort lifecycle", Annals of Tourism Research, 29 (1).

[4]. AGUILÓ, E.-ALEGRE, J.-SARD, M. (2003), “The persistence of sun and sand tourism model”, en Tourism Management, núm. 26.

[5]. AGUILÓ, P.-RIERA, A. (2003), "Las metodologías de valoración del medio ambiente: aplicaciones a Baleares", en G. LÓPEZ CASASNOVAS (Dir.), Islas Baleares. Serie Estudios Regionales, Fundació BBVA (Madrid).

[6]. ALCAIDE, J. (2003), Evolución económica de las regiones y provincias españolas en el siglo XX, Fundación BBVA (Bilbao).

[7]. ALCOVER, A.-SANSÓ, A.. (2007), "Un contraste formal de la teoría del ciclo de vida de los destinos turísticos. Aplicación al caso de Mallorca”, en AUTORES DIVERSOS, La actividad turística española en 2006, Editorial Universitaria Ramón Areces (Madrid).

[8]. ALEGRE, J.-POU, LL. (2002), "The Determinants of the Probability of Tourism Consumption: an Analysis with a Family Expenditure Survey", Working Papers, 39, Departament d'Economia Aplicada, Universitat de les Illes Balears.

[9]. ALEGRE, J.-POU, LL. (2003a), "La reducción del tiempo de estancia en los destinos vacacionales: implicaciones sobre el gasto turístico y la estacionalidad en las Islas Baleares", en G. LÓPEZ CASASNOVAS (Dir.), Islas Baleares. Serie Estudios Regionales, Fundación BBVA (Madrid).

[10]. ALEGRE, J.-POU, LL. (2003b), "El turismo de sol y playa desde la perspectiva de los consumidores europeos. Un nuevo desafío en el desarrollo turístico de Baleares", en G. LÓPEZ CASASNOVAS (Dir.), Islas Baleares. Serie Estudios Regionales, Fundació BBVA (Madrid)

[11]. ALENYÀ, M.-CLADERA, J. (2006), "Els reptes del turisme a les Balears", en A. FORCADES JUAN (Dir.), Repensem el model de creixement de les Illes Balears, Cercle d'Economia-Cambra de Comerç, Indústria i Navegació de Mallorca (Palma).

[12]. ANISI, D. (2005), "La macroeconomía al comienzo del siglo XXI: una reflexión sobre el uso y posterior abandono del llamado keynesianismo", Estudios de Economía Política, núm. 1.

[13]. APOSTOLOPOULOS, Y.-LOUKISSAS, P.-LEONTIDOU, L. (2001), Mediterranean Tourism. Facets in socioeconomic development and cultural change, Roudlege (Londres).

[14]. ARON, C.S. (1999), Working at Play: A History of the Vacations in the United States, Oxford University Press (Nova York).

[15]. ARTIGUES, A. (2001), "Turismo de espacios litorales e insulares", en D. A. BARRADO-J. CALABUIG (Edits.), Geografía mundial del turismo, Síntesis (Madrid).

[16]. AZAR, C. et alter (1996), "Socio-ecological indicators for sustainability", Ecological Economics, 18

[17]. BALAGUER, J.-CANTAVELLA, M. (2002), "Tourism as a long-run economic growth factor: the Spanish case", Applied Economics, 34.

[18]. BARANOWSKI, S. (2004), Strength through Joy: Consumerism and Mass Tourism in the Third Reich, Cambridge University Press (Cambridge).

[19]. BARANOWSKI, S.-FURLOUGH, E. (2001), Being Elsewhere: Tourism, Consumer Culture, and Identiy in Modern Europe and North America, The University of Michigan Press (Michigan).

[20]. BATTILANI, P. (2001), Vacanze di pochi, vacanze di tutti. L'evoluzione del turismo europeo, Il Mulino (Bolònia).

[21]. BLÁZQUEZ, M.-MURRAY, I.-GARAU, J.M. (2002), El tercer boom. Indicadors de sostenibilitat del turisme de les Illes Balears, 1989-1999, Centre d'Investigació i Tecnologies Turístiques de les Illes Balears (Palma).

[22]. BUADES, J. (2004), On brilla el sol. Turisme a Balears abans del boom, Res Publica Edicions (Eivissa).

[23]. BUTLER, R.W. (1980), "The concept of a tourist area cycle of evolution: implications for management of resources", Canadian Geographer, 24 (1).

[24]. CALS, J. (2003), "Revisión de un turismo mediterráneo", Annals of Tourism Research, vol. 5, núm. 2.

[25]. CAÑADA, A. (2004), "Cuenta Satélite del Turismo de España (CSTE): características, métodos y resultados", en E. URIEL-R. HERNÁNDEZ (Coords.), Análisis y tendencias del turismo, Pirámide (Madrid).

[26]. CAPÓ, J. (2003), "Especialización productiva: una nota sobre la enfermedad balear", en G. LÓPEZ CASASNOVAS (Dir.), Islas Baleares. Serie Estudios Regionales, Fundació BBVA (Madrid).

[27]. CAPÓ, J.-RIERA, A.-ROSSELLÓ, J. (2005), "Duth disease in tourism economies. Evidences from Spain", en Documents de Treball del Centre de Recerca Econòmica UIB-Sa Nostra, www.cre.uib.es.

[28]. CAPÓ, J.-RIERA, A.-ROSSELLÓ, J. (2006), "Una revisión del análisis económico del turismo", Estudios de Economía Política, núm. 5.

[29]. CHOY, D. J. (1992), "Life Cycle Models por Pacific Islands", Journal of Travel Research, vol. 30 (3).

[30]. CHRISTALLER, W. (1963), "Some considerations of Tourism Location in Europe: the peripheral regions-underdeveloped countries-recreation areas", Regional Science Association Papers, vol. 12

[31]. CIRER, J.C. (2009), La invenció del turisme de masses a Mallorca, Institut Balear d'Economia, Conselleria d'Economia i Hisenda, Govern de les Illes Balears (Palma).

[32]. CORDEN, M.W. (1984), "Booming sector and Dutch Disease Economies: Survey and Consolidation", Oxford Economic Papers, núm. 36.

[33]. CORDEN, M.W.-NEARY, P. (1982), "Booming sector and de-industrialization in a small open economy”, The Economic Journal, núm. 92.

[34]. DEBBAGE K.G (1990), "Oligopoly and the Resort Cycle in the Bahamas", Annals of Tourism Research, Vol. 17.

[35]. FERNÁNDEZ FÚSTER, L. (1991), Geografía general del turismo de masas, Ariel (Madrid).

[36]. FORCADES JUAN, A. (Dir.) (2006), Repensem el model de creixement de les Illes Balears, Cercle d'Economia-Cambra de Comerç, Indústria i Navegació de Mallorca (Palma).

[37]. FUJTA, M.-KRUGMAN, P.-VENABLES, A.J. (2000), Economía espacial. Las ciudades, las regiones y el comercio internacional, Ariel (Barcelona).

[38]. FULLANA, P.-AYUSO, S. (2002), Turismo sostenible, Rubes (Barcelona).

[39]. GARAU, J. (2006), “Crecimiento en las economías turísticas insulares: evidencias empíricas de la 'trampa' del turismo", working paper, inèdit.

[40]. GARAU, J. (2010), Tourist satisfaction, dissatisfaction and place attachment at sun and sand mass tourism destinations, Doctoral Thesis, Universitat de les Illes Balears (Palma).

[41]. GETZ. D. (1992), "Tourism Planning and Destination Life Cycle", Annals of Tourism Research, Vol. 19.

[42]. GIRELLI BOCCI, A.M. (2006), L'industria dell'ospitalità a Roma. Secoli XIX-XX, CEDAM (Padova). 
[43]. HANLEY, N. et alter (1999), "Measuring sustainability: a time series of alternative indicators for Scotland", Ecological Economics, 28.

[44]. HAYWOOD, K.M., (1986), “Can the Tourist-Area Life Cycle be Made Operational?” Tourism Management, Vol. 7.

[45]. HIRSCHMAN, A. O. (1960), Las etapas del desenvolvimiento económico, F.C.E. (Méjico).

[46]. HOVINEN, G.R. (1981), “A Tourist Cycle in Lancaster County Pennsylvania”, Canadian Geographer, Vol. 25.

[47]. HOVINEN, G.R. (1981), "Revisiting the destination lifecycle model", Annals of Tourism Research, 29 (1).

[48]. IOANNIDES, D. (1992), "Tourism Development Agents: The Cypriot Resort Cycle", Annals of Tourism Research, Vol. 19.

[49]. JACOBS, M. (1996), La economía verde. Medio ambiente, desarrollo sostenible y la política del futuro, Icaria (Madrid).

[50]. KRUGMAN, P. (1992), Geografía y comercio, Antoni Bosch Editor (Barcelona).

[51]. LEYBOURNE, S.-NEWBOLD, P.-VOUGAS, D. (1998), "Unit Roots and Smoth transistions": Journal of Time Series Análisis, Vol. 19(1).

[52]. LÓPEZ CASASNOVAS, G. (Dir.) (2003), Islas Baleares. Serie Estudios Regionales, Fundació BBVA (Madrid).

[53]. LUNDTORP, S.-WANHILL, S. (2001), "The resort lifecycle theory: generating processes and estimation", Annals of Tourism Research, vol. 28, núm. 1 .

[54]. MADDISON, A. (1995), Monitoring the world economy, OCDE (París)

[55]. MADDISON, A. (1997), "The nature and functioning of European Capitalism: a historical and comparative perspective", Banca Nationale del Lavoro Quaterly Review, diciembre.

[56]. MADDISON, A. (2003), The world economy: Historical Statistics, OCDE (París).

[57]. MANERA, C. (2001), Història del creixement econòmic a Mallorca, 1700-2000, Lleonard Muntaner editor (Palma).

[58]. MANERA, C.-GARAU, J. (2005), "Los costes de la insularidad en el desarrollo económico. Un contraste en el Mediterráneo occidental”, Mediterráneo Económico, núm.7.

[59]. MARTORELL, O. (2002), Cadenas Hoteleras. Análisis del Top 10, Ariel (Barcelona).

[60]. MASCARÓ, P.-NAVINÉS, F. (2004), "Turisme i territori, elements claus per explicar la competitivitat i la productivitat a les Illes Balears", en AUTORS DIVERSOS, Comportament de la productivitat i la competitivitat a les Illes Balears, Consell Econòmic Social (Palma).

[61]. MASSIEU, A. (2004), "El sector turístico visto desde la OMT: una reflexión a partir de la coyuntura reciente a nivel mundial", en E. URIEL-R. HERNÁNDEZ (Coords.), Análisis y tendencias del turismo, Pirámide (Madrid).

[62]. MEYER-ARENDT, K. (1985), "The Grand Isle, Louisiana Resort Cycle” Annals of Tourism Research, Vol. 12.

[63]. MIOSSEC, J.M. (1977): “Un Modèle de l'Espace Turistique”, L'Espace Geographique, Vol. 6.

[64]. MORLEY, C.L. (1992), “A microeconomic theroy of international tourism demand”, Annals of Tourism Research, núm. 19.

[65]. MURRAY, I.-GARAU, J.M.-BLÀZQUEZ, M. (2001), "La qüestió energètica a les Illes Balears (1989-1999), en C. MANERA (Dir.), Història ecològica a les Illes Balears. Estudis sobre energia, economia i medi ambient, Lleonard Muntaner Editor (Palma).

[66]. MURRAY, I.-RULLAN, O.-BLÀZQUEZ, M. (2005), "Las huellas territoriales de deterioro ecológico. El trasfondo oculto de la explosión turística en Baleares”, Geo-Crítica. Scripta Nova, núm. 199.

[67]. NAVINÉS, F. (2006), "Algunes reflexions fetes des de l'enfocament clàssic de l'excedent sobre el procés de terciarització i especialització productiva: el cas de Balears”, en A. FORCADES JUAN (Dir.), Repensem el model de creixement de les Illes Balears, Cercle d'Economia-Cambra de Comerç, Indústria i Navegació de Mallorca (Palma).

[68]. OGLETHORPE, M. (1984): “Tourism in Malta. A Crisis of Dependence", Leisure Studies, Vol. 3.

[69]. OMT (2003), Tourism Highliths. Edition 2003, www.world-tourism.org

[70]. OMT (2004), Compendium of Tourism Statistics. Data 1998-2002, World Tourism Organization (Madrid).

[71]. OMT (2004), Tourism Market Trends, www.world-tourism.org

[72]. OMT (varios años), Anuario de estadísticas del turismo, World Tourism Organization (Madrid).

[73]. OMT (varios años), Compendium of Tourism Statistics, World Tourism Organization (Madrid).

[74]. PALMER, T.-RIERA, A. (2002), "Balance ecológico y económico del turismo de masas", Estudis d'Història Econòmica, núm. 19.

[75]. PAPATHEODOROU, A. (2003), "Exploring the evolutions of tourism resorts", Annals of Tourism Research, vol. 31, núm. 1.

[76]. PAPATHEODOROU, A.-SONG, H. (2005), "International tourism forecasts: time-series analysis of world and regional data", Tourism Economics, 11 (1).

[77]. PEARCE, D.G. (1995), Tourism Today. A Geographical Analysis, Longman Group Limited (Essex).

[78]. PÉREZ, C. (2004), Revoluciones tecnológicas y capital financiero. Las dinámicas de las grandes burbujas y las épocas de bonanza, Siglo XXI (México).

[79]. PICORNELL, C.-PICORNELL, M. (2002), “L'espai turístic de les Illes Balears. Un cicle de vida d'una àrea turística? Evolució i planificació de la darrera dècada”, en M. PICORNELL-A. POMAR (Edits.), L'espai turístic, Institut d'Estudis Ecològics (Palma).

[80]. PLOG, S.C. (1973): "Why Destination Areas Rise and Fall in Popularity?", The Cornell Hotel and Restaurant Administration Quarterly, Vol. 14

[81]. POON, A. (1993), "Tourism, technology and competitive strategies", CAB International, Wallingford.

[82]. PRIESTLEY, G. Y MUNDET, L. (1998), "The Post-Stagnation Phase of the Resort Cycle", Annals of Tourism Research, Vol. 25 (1)

[83]. RAMÓN, A. B. (2002), La expansión internacional del sector hotelero español, Caja de Ahorros del Mediterráneo.

[84]. REES, W.-WACKERNAGEL, M. (1996), Our Ecological Footprint. Reducing Human Impact on Earth, New Society Publishers (Canadà).

[85]. REIG, E.-PICAZO, A. (1998), Capitalización y crecimiento de la economía balear, 1955-1996, Fundación BBVA (Bilbao).

[86]. RICHARDSON, J. I. (1999), A History of Australian Travel and Tourism, Hospitality Press (Elsternwick, Austràlia).

[87]. ROMER, P. (1986), "Increasing returns and long-run growth", Journal of Political Economy, 94.

[88]. ROSSELLÓ, J. (2003), "Evolución y perspectivas de la demanda turística en Baleares”, en G. LÓPEZ CASASNOVAS (dir.), Islas Baleares. Serie Estudios Regionales, Fundación BBVA (Madrid).

[89]. ROZENBLAT, C.-CICILLE, P. (2003), Les villes européennes. Analyse comparative, Datar/La Documentation française (París).

[90]. RUSSEL, R.-FAULKNER, B. (2004), "Entrepeneurship, chaos and the tourism areal lifecycle", Annals of Tourism Research, vol. 31, núm. 1.

[91]. SALVÀ, P. (2003), "La realidad geodemográfica de las Islas Baleares: pautas de la evolución de su población y el impacto de los flujos inmigratorios”, en G. LÓPEZ CASASNOVAS (Dir.), Islas Baleares. Serie Estudios Regionales, Fundació BBVA (Madrid).

[92]. SASTRE, A. (1994), Mercat turístic balear, Institut d'Estudis Baleàrics, Govern de les Illes Balears (Palma).

[93]. SEGRETO, L.-MANERA, C.-POHL, M. (Eds.) (2009), Europe at the Seaside. The Economic History of Mass Tourism in the Mediterranean, Berghan Books (New York-Oxford). 
[94]. SEGUí, M.-SERVERA, J. (2001), "La vocación turística del territorio”, en D. A. BARRADO-J. CALABUIG (Edits.), Geografía mundial del turismo, Síntesis (Madrid).

[95]. SINCLAIR, M.T.-STABLER, M. (1997), The Economics of Tourism, Routledge (Londres-Nova York).

[96]. SOSHIRODA, A. (2005), "Inbound tourisme policies in Japan from 1859 to 2003", Annals of Tourism Research, vol. 32 , núm. 4.

[97]. STANSFIELD, C.A. (1978), "Atlantic City and The Resort Cycle: Background to the Legislation of Gambling", Annals of Tourism Research, Vol. 5.

[98]. THUROT, J.M. (1973), Le Tourisme Tropical Balnéaire; le modele caraibe et ses extensions, CHET (Aix en Provence).

[99]. TISSOT, L. (Dir.) (2003), Development of a Tourist Industry in the 19th and 20th Centuries. International Perspectives, Alphil (Neuchâtel).

[100]. TOIVONEN, T. (2004), "Changes in the propensity to take holiday trips abroad in EU countries between 1985 and 1997", Tourism Economics, 10 (4).

[101]. VELLAS, F., (2004), Economía y política del turismo internacional, Síntesis (Madrid).

[102]. WALTON, J. (2002), "Aproximación a la historia del turismo en el Reino Unido, siglos XVIII-XX”, Historia Contemporánea, núm. 25.

[103]. WEAVER, D.B. (1998), "Peripheries of the Peripheries; Tourism in Tobago and Bermuda", Annals of Tourism Research, Vol. 25 (2).

[104]. WILKINSON, P.F. (1987), “Tourism in Small islands Nations: A Fragile Dependence”, Leisure Studies, Vol. 6.

[105]. WILliANS, M.T. (1993), "An Expansion of the Tourist Site Cycle Model: The Case of Minorca (Spain)", The Journal of Tourism Studies, Vol. 4, núm 2. 